\title{
Colwellia chukchiensis sp. nov., a psychrotolerant bacterium isolated from the Arctic Ocean
}

Correspondence

Yong Yu

yuyong@pric.gov.cn

\author{
Yong Yu, Hui-Rong Li and Yin-Xin Zeng
}

SOA Key Laboratory for Polar Science, Polar Research Institute of China, Shanghai 200136, PR China

\begin{abstract}
A novel psychrotolerant bacterial strain, $\mathrm{BCw} 111^{\top}$, was isolated from seawater samples from the Chukchi Sea in the Arctic Ocean. Cells of strain $\mathrm{BCw} 111^{\top}$ were Gram-negative, motile, facultatively anaerobic, curved rods and were able to grow at $0-30{ }^{\circ} \mathrm{C}$ (optimum $23-25{ }^{\circ} \mathrm{C}$ ). Strain $\mathrm{BCw} 111^{\top}$ had $\mathrm{Q}-8$ as the major respiratory quinone and contained iso- $\mathrm{C}_{15: 0} 2-\mathrm{OH}$ and/or $\mathrm{C}_{16: 1} \omega 7 c(28.13 \%), \mathrm{C}_{16: 0}(13.28 \%)$ and $\mathrm{C}_{17: 1}(12.90 \%)$ as the major cellular fatty acids. The genomic DNA G +C content was 41.3 mol\%. Phylogenetic analysis based on 16S rRNA gene sequences indicated that strain $\mathrm{BCw} 11^{\top}$ formed a distinct lineage within the genus Colwellia and exhibited the highest $16 \mathrm{~S}$ rRNA gene sequence similarity with Colwellia polaris $537^{\top}(97.8 \%)$ and Colwellia aestuarii SMK-10 $0^{\top}(97.1 \%)$. Based on phenotypic characteristics, phylogenetic analysis and DNA-DNA relatedness, a novel species, Colwellia chukchiensis sp. nov., is proposed. The type strain is BCw $111^{\top}$ (=CGMCC $1.9127^{\top}=$ LMG $25329^{\top}=$ DSM $\left.22576^{\top}\right)$.
\end{abstract}

The genus Colwellia, which belongs to the family Colwelliaceae, was originally proposed by Deming et al. (1988). At the time of writing, the genus Colwellia comprised 11 species: Colwellia psychrerythraea (the type species) and C. hadaliensis (Deming et al., 1988), $C$. demingiae, C. hornerae, C. psychrotropica and C. rossensis (Bowman et al., 1998), C. maris (Yumoto et al., 1998), C. piezophila (Nogi et al., 2004), C. aestuarii (Jung et al., 2006), C. polaris (Zhang et al., 2008) and C. asteriadis (Choi et al., 2010). During screening of cold-adapted bacteria from seawater samples from the Chukchi Sea in the Arctic Ocean $\left(73^{\circ} 00^{\prime} 00^{\prime \prime} \mathrm{N} 169^{\circ} 32^{\prime} 44^{\prime \prime} \mathrm{W}\right)$, we isolated a psychrotolerant bacterium, strain $\mathrm{BCw} 111^{\mathrm{T}}$. Phenotypic, genotypic and phylogenetic data indicated that the new isolate could represent a novel species of the genus Colwellia.

Seawater at a depth of $60 \mathrm{~m}$ was collected for the isolation of bacterial strains during the Second Chinese National Arctic Research Expedition cruise of the icebreaker Xue Long. Strain $\mathrm{BCw} 111^{\mathrm{T}}$ was isolated by the dilution-plating technique on marine agar (MA; Difco) after incubation at $4{ }^{\circ} \mathrm{C}$ for 4 weeks. Colwellia polaris CGMCC $1.6132^{\mathrm{T}}$ and Colwellia aestuarii CGMCC $1.6965^{\mathrm{T}}$ were obtained from the CGMCC and used as reference strains. Strains were stored at $-80{ }^{\circ} \mathrm{C}$ in marine 2216 broth (MB; Difco) supplemented with $30 \%$ (v/v) glycerol.

Cell morphology was examined using phase-contrast microscopy (Eclipse 80i; Nikon) and transmission electron

The GenBank/EMBL/DDBJ accession number for the 16S rRNA gene sequence of strain $\mathrm{BCw} 111^{\top}$ is FJ889599.

Two supplementary figures and a supplementary table are available with the online version of this paper. microscopy (JEM-100CX; JEOL). Colony morphology was observed on MA after incubation at $25^{\circ} \mathrm{C}$. Growth at 0 $37{ }^{\circ} \mathrm{C}$ was investigated in $\mathrm{MB}$ for $5-30$ days. Growth at pH 4-11 was determined by the method of Zhang et al. (2009). Growth with $0-10 \%$ (w/v) $\mathrm{NaCl}$ (in increments of $1 \%$ ) was tested in a medium containing $\left(1^{-1}\right) 5 \mathrm{~g} \mathrm{MgCl}_{2}$, $2 \mathrm{~g} \mathrm{MgSO}_{4}, 0.5 \mathrm{~g} \mathrm{CaCl}_{2}, 1 \mathrm{~g} \mathrm{KCl}$ and $5 \mathrm{~g}$ peptone and adjusted to $\mathrm{pH} 7.5$ with $\mathrm{KOH}$ (Smibert \& Krieg, 1994). Growth under anaerobic conditions was determined by incubation in an anaerobic chamber (AnaeroJar; Oxoid). Hydrolysis of casein, starch, Tween 80 and gelatin was tested as described by Smibert \& Krieg (1994) on MA. Gram stain, flagella stain and tests for catalase and oxidase were performed using conventional methods (Dong \& Cai, 2001). Substrate utilization, activities of constitutive enzymes and other physiological properties were determined using the API $50 \mathrm{CH}$, API $20 \mathrm{E}$, API $20 \mathrm{NE}$ and API ZYM systems (bioMérieux) with inoculum prepared in $3 \%$ $(\mathrm{w} / \mathrm{v})$ sea salt solution (Sigma). Acid production from carbohydrates was determined using the API $50 \mathrm{CH}$ system with $3 \%(w / v) ~ N a C l$ added to the API $50 \mathrm{CHB} / \mathrm{E}$ medium. All tests were performed in duplicate. The morphological, physiological and biochemical characteristics of strain BCw $111^{\mathrm{T}}$ are given in the species description and Table 1.

Respiratory quinones were extracted and purified according to Collins (1985) and analysed by HPLC (Wu et al., 1989). For fatty acid methyl ester analysis, cells of strain BCw $111^{\mathrm{T}}$, C. polaris CGMCC $1.6132^{\mathrm{T}}$ and C. aestuarii CGMCC $1.6965^{\mathrm{T}}$ were harvested from MA after incubation at $25^{\circ} \mathrm{C}$ for $48 \mathrm{~h}$. The fatty acid methyl esters were extracted and prepared according to the standard protocol of the Microbial Identification system (MIDI; Sasser, 1990). To 
Table 1. Characteristics that differentiate strain $B C w 111^{\top}$ from its closest phylogenetic neighbours

Strains: 1, Colwellia chukchiensis sp. nov. BCw11 $11^{\mathrm{T}} ; 2$, C. polaris CGMCC $1.6132^{\mathrm{T}} ; 3$, C. aestuarii CGMCC $1.6965^{\mathrm{T}}$. Data were obtained in this study unless indicated. All strains are positive for cytochrome oxidase, catalase, alkaline phosphatase and leucine arylamidase and utilize D-glucose as a sole carbon source.

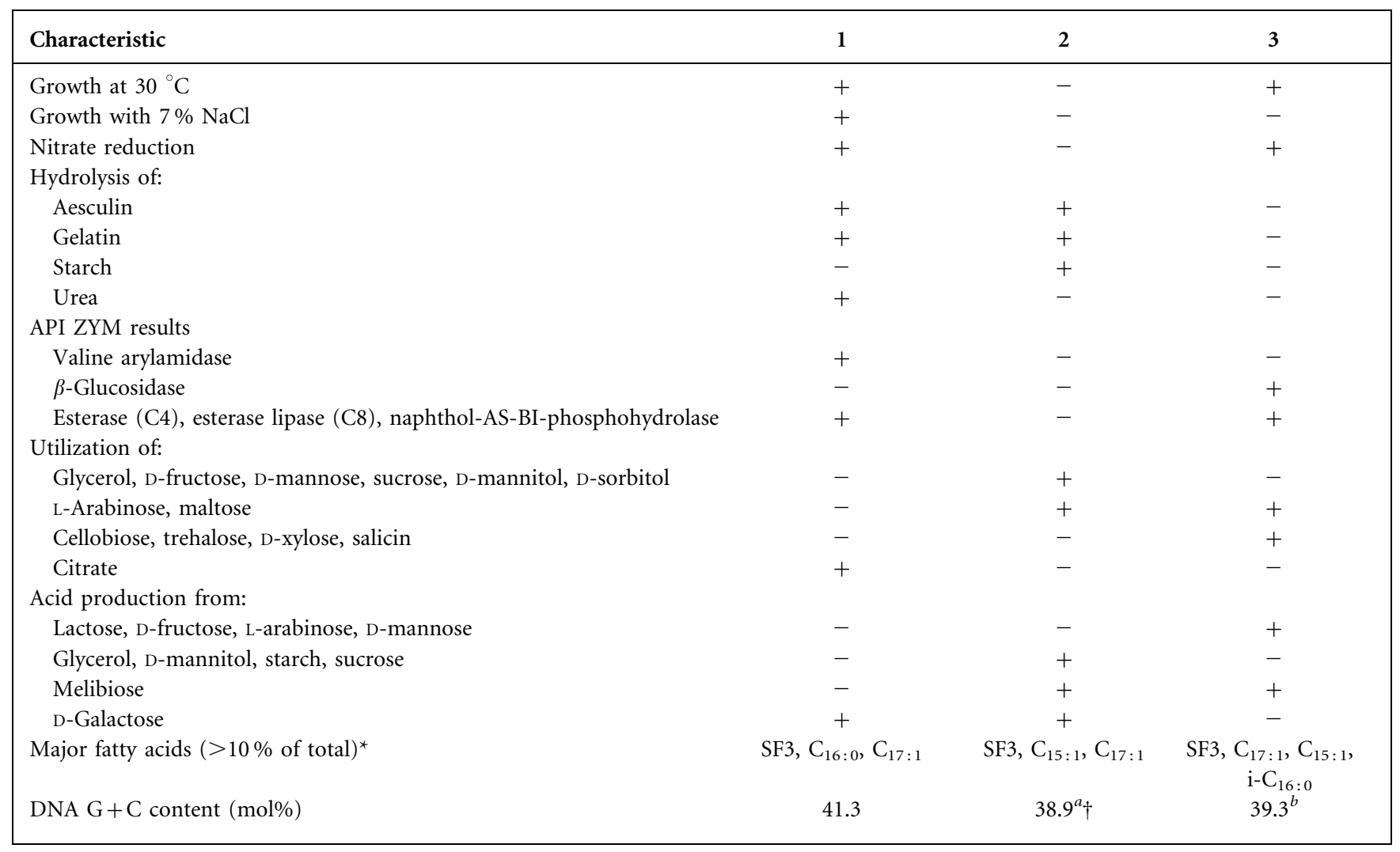

${ }^{*} \mathrm{SF} 3$, Summed feature 3 (iso- $\mathrm{C}_{15: 0} 2-\mathrm{OH}$ and/or $\mathrm{C}_{16: 1} \omega 7 c$ ); $\mathrm{i}$, iso-branched.

$\dagger$ Data taken from: $a$, Zhang et al. (2008); b, Jung et al. (2006).

determine the DNA G $+\mathrm{C}$ content of strain $\mathrm{BCw} 111^{\mathrm{T}}$, DNA was extracted using a French pressure cell (Thermo Spectronic) and purified by chromatography on hydroxyapatite as described by Cashion et al. (1977). The G+C content was determined by HPLC according to the method of Mesbah et al. (1989) with non-methylated lambda DNA (Sigma) and DNA from Bacillus subtilis DSM 402, Xanthomonas campestris pv. campestris DSM $3586^{\mathrm{T}}$ and Streptomyces violaceoruber DSM 40783 as references. Cells of strain $\mathrm{BCw} 111^{\mathrm{T}}$ contained ubiquinone-8 (Q-8; $98 \%$ ) and ubiquinone-7 (Q-7; 2\%) as the respiratory quinones. The major cellular fatty acids $(>10 \%$ of the total) of strain $\mathrm{BCw}_{111^{\mathrm{T}}}$ were iso- $\mathrm{C}_{15: 0} 2-\mathrm{OH}$ and/or $\mathrm{C}_{16: 1} \omega 7 c$ $2-\mathrm{OH}$ $(28.13 \%), \mathrm{C}_{16: 0}(13.28 \%)$ and $\mathrm{C}_{17: 1}(12.90 \%)$. The fatty acid profiles of strain BCw111 ${ }^{\mathrm{T}}$, C. polaris CGMCC $1.6132^{\mathrm{T}}$ and C. aestuarii CGMCC $1.6965^{\mathrm{T}}$ are given in Supplementary Table S1 (available in IJSEM Online). The DNA G +C content of strain $\mathrm{BCw} 111^{\mathrm{T}}$ was $41.3 \mathrm{~mol} \%$.

For sequencing and phylogenetic analysis of the 16S rRNA gene of strain $\mathrm{BCw} 111^{\mathrm{T}}$, DNA was extracted and purified with a commercial kit (BioDev, Beijing, China) and amplified by PCR using universal primers $8 \mathrm{f}$
(5'-AGAGTTTGATCCTGGCTCAG-3') and 1492r (5'GGTTACCTTGTTACGACTT-3') (Weisburg et al., 1991). The purified PCR product was ligated and cloned into pMD 18-T (TaKaRa) according to the manufacturer's instructions. Sequencing reactions were carried out using an ABI BigDye Terminator 3.1 sequencing kit and an automated DNA sequencer (ABI 3730; Applied Biosystems). The nearly complete (1463 nt) 16S rRNA gene sequence of strain $\mathrm{BCw} 111^{\mathrm{T}}$ was submitted to public databases to search for similar sequences using the BLAST algorithm. The identification of phylogenetic neighbours and the calculation of pairwise 16S rRNA gene sequence similarities were achieved using the EzTaxon server (http:// www.eztaxon.org/; Chun et al., 2007). Sequences were aligned using CLUSTAL x version 1.8 (Thompson et al., 1997) and edited manually using the BioEdit sequence alignment editor version 5.0.9 (Hall, 1999). Phylogenetic trees were constructed using the neighbour-joining and maximum-parsimony methods with Kimura's two-parameter model in MEGA version 4 (Tamura et al., 2007) and the maximum-likelihood method in PHYLIP version 3.69 (Felsenstein, 2009). 
The phylogenetic analysis showed that strain $\mathrm{BCw} 111^{\mathrm{T}}$ grouped with the members of the genus Colwellia and formed a distinct cluster with C. polaris $537^{\mathrm{T}}$ and $C$. aestuarii SMK- $10^{\mathrm{T}}$, which was supported by a bootstrap value of $100 \%$ in the neighbour-joining tree (Fig. 1). Similar tree topologies were found with the maximumparsimony and maximum-likelihood algorithms (Supplementary Figs S1 and S2). Pairwise analysis revealed that strain BCw $111^{\mathrm{T}}$ exhibited 97.8 and $97.1 \% 16 \mathrm{~S}$ rRNA gene sequence similarity with C. polaris $537^{\mathrm{T}}$ and $C$. aestuarii SMK $-10^{\mathrm{T}}$, respectively, and $<95.9 \% 16 \mathrm{~S}$ rRNA gene sequence similarity with other members of the genus Colwellia. Although there is no precise correlation between 16S rRNA gene sequence similarity and species delineation, it is generally recognized that $\geqslant 3 \%$ sequence divergence is significant (Stackebrandt \& Goebel, 1994).

To differentiate strain $\mathrm{BCw} 111^{\mathrm{T}}$ from its closest phylogenetic neighbours, DNA-DNA hybridization was carried out using the liquid renaturation method (De Ley et al., 1970) as modified by Huß et al. (1983) using a DU800 spectrophotometer (Beckman) with a thermal controller at $65{ }^{\circ} \mathrm{C}$. DNA-DNA relatedness between strain BCw $111^{\mathrm{T}}$ and C. polaris CGMCC $1.6132^{\mathrm{T}}$ and C. aestuarii CGMCC $1.6965^{\mathrm{T}}$ was $42.6 \pm 6.5$ and $19.8 \pm 7.8 \%$, respectively. These values indicated that strain $\mathrm{BCw} 111^{\mathrm{T}}$ was distinct from these type strains (Wayne et al., 1987).

The genetic distinctiveness of strain $\mathrm{BCw} 111^{\mathrm{T}}$ was supported by phenotypic characteristics. In contrast to $C$. polaris CGMCC $1.6132^{\mathrm{T}}$ and C. aestuarii CGMCC $1.6965^{\mathrm{T}}$, strain $\mathrm{BCw} 111^{\mathrm{T}}$ was able to grow with $7 \% \mathrm{NaCl}$, to hydrolyse urea and to utilize citrate and it contained $\mathrm{C}_{15: 0}$, $\mathrm{C}_{18: 1} \omega 7 c$ and larger amounts of $\mathrm{C}_{16: 0}$ (Table 1 and Supplementary Table S1).

Therefore, on the basis of phenotypic, phylogenetic and genotypic data, strain $\mathrm{BCw} 111^{\mathrm{T}}$ represents a novel species of the genus Colwellia, for which the name Colwellia chukchiensis sp. nov. is proposed.

\section{Description of Colwellia chukchiensis sp. nov.}

Colwellia chukchiensis (chuk.chi.en'sis. N.L. fem. adj. chukchiensis named after the Chukchi Sea, the geographical origin of the type strain).

Cells are Gram-negative, psychrotolerant, curved rods $(0.5-1.0 \times 1.1-4.5 \mu \mathrm{m})$. Motile by means of a single polar flagellum. Growth occurs under anaerobic conditions on MA and on MA supplemented with nitrate. Colonies are non-pigmented, convex, circular and smooth with entire edges. Growth occurs at $0-30{ }^{\circ} \mathrm{C}$ (optimum $23-25{ }^{\circ} \mathrm{C}$ ), but not at $33{ }^{\circ} \mathrm{C}$, at $\mathrm{pH} 5.0-10.5$ (optimum $\mathrm{pH}$ 6.0-8.0) and with $0.5-8.0 \% \quad(\mathrm{w} / \mathrm{v}) \mathrm{NaCl}$, but not without $\mathrm{NaCl}$. Catalase- and cytochrome oxidase-positive. Hydrogen sulfide production, indole production and VogesProskauer tests are negative. Nitrate is reduced to nitrogen. Casein, gelatin and Tween 80 are hydrolysed. Positive for alkaline phosphatase, esterase (C4), esterase lipase (C8), naphthol-AS-BI-phosphohydrolase, valine arylamidase and leucine arylamidase, but negative for arginine dihydrolase, lysine decarboxylase, ornithine decarboxylase, lipase (C14), $\alpha$-chymotrypsin, acid phosphatase, trypsin, cystine arylamidase, $\alpha$-galactosidase, $\beta$-galactosidase, $\beta$-glucuronidase, $\alpha$-glucosidase, $N$-acetyl- $\beta$-glucosaminidase, $\alpha$-mannosidase and $\alpha$-fucosidase. With API $50 \mathrm{CH}$, D-galactose, D-glucose and citrate are utilized as sole carbon sources and acid is produced from D-galactose and citrate. The major cellular fatty acids $(>10 \%)$ are iso- $\mathrm{C}_{15: 0} 2-\mathrm{OH}$ and/or $\mathrm{C}_{16: 1} \omega 7 c$, $\mathrm{C}_{16: 0}$ and $\mathrm{C}_{17: 1}$. The major respiratory quinone is $\mathrm{Q}-8$. The DNA G + C content of the type strain is $41.3 \mathrm{~mol} \%$.

The type strain is BCw $111^{\mathrm{T}}$ (=CGMCC $1.9127^{\mathrm{T}}=\mathrm{LMG}$ $25329^{\mathrm{T}}=$ DSM $\left.22576^{\mathrm{T}}\right)$, isolated from the Chukchi Sea in the Arctic Ocean $\left(73^{\circ} 00^{\prime} 00^{\prime \prime} \mathrm{N} 169^{\circ} 32^{\prime} 44^{\prime \prime} \mathrm{W}\right)$.

\section{Acknowledgements}

We thank the staff of the DSMZ, especially Dr Peter Schumann and Dr Susanne Verbarg, for analysis of DNA G + C content and quinones. We also thank the Chinese Arctic and Antarctic Administration, which supports the field work of this research. This

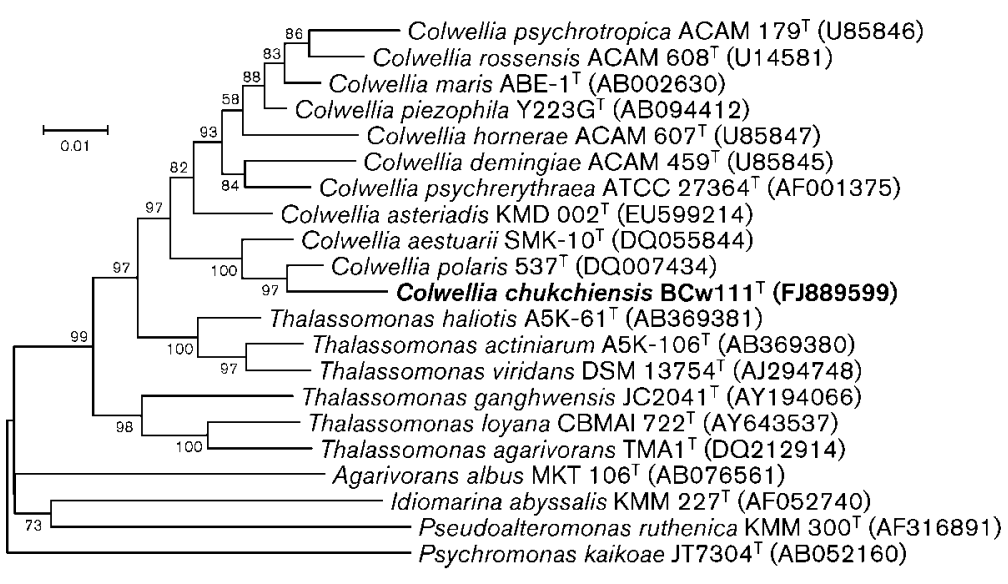

Fig. 1. Neighbour-joining tree based on 16S rRNA gene sequences showing the phylogenetic relationships of strain $\mathrm{BCw} 111^{\top}$ and related taxa. Bootstrap values $(>50 \%)$ based on 1000 resampled datasets are shown at branch nodes. Bar, $1 \%$ sequence divergence. 
work was supported by IPY 2007-2008 Chinese Programme, the National Key Technology R\&D Program of China (grant no. 2006BAB18B07), the National Natural Science Foundation of China (grant no. 30500001) and the National Infrastructure of Natural Resources for Science and Technology Program of China (grant no. 2005DKA21209).

\section{References}

Bowman, J. P., Gosink, J. J., McCammon, S. A., Lewis, T. E., Nichols, D. S., Nichols, P. D., Skerratt, J. H., Staley, J. T. \& McMeekin, T. A. (1998). Colwellia demingiae sp. nov., Colwellia hornerae sp. nov., Colwellia rossensis sp. nov. and Colwellia psychrotropica sp. nov.: psychrophilic Antarctic species with the ability to synthesize

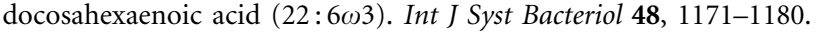

Cashion, P., Holder-Franklin, M. A., McCully, J. \& Franklin, M. (1977). A rapid method for the base ratio determination of bacterial DNA. Anal Biochem 81, 461-466.

Choi, E. J., Kwon, H. C., Koh, H. Y., Kim, Y. S. \& Yang, H. O. (2010). Colwellia asteriadis sp. nov., a marine bacterium isolated from the starfish Asterias amurensis. Int J Syst Evol Microbiol 60, 1952-1957.

Chun, J., Lee, J.-H., Jung, Y., Kim, M., Kim, S., Kim, B. K. \& Lim, Y.-W. (2007). EzTaxon: a web-based tool for the identification of prokaryotes based on $16 \mathrm{~S}$ ribosomal RNA gene sequences. Int J Syst Evol Microbiol 57, 2259-2261.

Collins, M. D. (1985). Isoprenoid quinone analysis in classification and identification. In Chemical Methods in Bacterial Systematics, pp. 267-287. Edited by M. Goodfellow \& D. E. Minnikin. London: Academic Press.

De Ley, J., Cattoir, H. \& Reynaerts, A. (1970). The quantitative measurement of DNA hybridization from renaturation rates. Eur J Biochem 12, 133-142.

Deming, J. W., Somers, L. K., Straube, W. L., Swartz, D. G. \& MacDonell, M. T. (1988). Isolation of an obligately barophilic bacterium and description of a new genus, Colwellia gen. nov. Syst Appl Microbiol 10, 152-160.

Dong, X.-Z. \& Cai, M.-Y. (2001). Manual for the Systematic Identification of General Bacteria, pp. 370-398. Beijing: Science Press (in Chinese).

Felsenstein, J. (2009). PHYLIP (phylogeny inference package) version 3.69. Distributed by the author. Department of Genome Sciences, University of Washington, Seattle, USA.

Hall, T. A. (1999). BioEdit: a user-friendly biological sequence alignment editor and analysis program for Windows 95/98/NT. Nucleic Acids Symp Ser 41, 95-98.

Huß, V. A. R., Festl, H. \& Schleifer, K. H. (1983). Studies on the spectrophotometric determination of DNA hybridization from renaturation rates. Syst Appl Microbiol 4, 184-192.
Jung, S.-Y., Oh, T.-K. \& Yoon, J.-H. (2006). Colwellia aestuarii sp. nov., isolated from a tidal flat sediment in Korea. Int J Syst Evol Microbiol 56, 33-37.

Mesbah, M., Premachandran, U. \& Whitman, W. B. (1989). Precise measurement of the $\mathrm{G}+\mathrm{C}$ content of deoxyribonucleic acid by highperformance liquid chromatography. Int J Syst Bacteriol 39, 159-167.

Nogi, Y., Hosoya, S., Kato, C. \& Horikoshi, K. (2004). Colwellia piezophila sp. nov., a novel piezophilic species from deep-sea sediments of the Japan Trench. Int J Syst Evol Microbiol 54, 16271631.

Sasser, M. (1990). Identification of bacteria by gas chromatography of cellular fatty acids, MIDI Technical Note 101. Newark, DE: MIDI Inc.

Smibert, R. M. \& Krieg, N. R. (1994). Phenotypic characterization. In Methods for General and Molecular Bacteriology, pp. 607-654. Edited by P. Gerhardt, R. G. E. Murray, W. A. Wood \& N. R. Krieg. Washington, DC: American Society for Microbiology.

Stackebrandt, E. \& Goebel, B. M. (1994). Taxonomic note: a place for DNA-DNA reassociation and $16 \mathrm{~S}$ rRNA sequence analysis in the present species definition in bacteriology. Int J Syst Bacteriol 44, 846849.

Tamura, K., Dudley, J., Nei, M. \& Kumar, S. (2007). MEGA4: molecular evolutionary genetics analysis (MEGA) software version 4.0. Mol Biol Evol 24, 1596-1599.

Thompson, J. D., Gibson, T. J., Plewniak, F., Jeanmougin, F. \& Higgins, D. G. (1997). The CLUSTAL_X windows interface: flexible strategies for multiple sequence alignment aided by quality analysis tools. Nucleic Acids Res 25, 4876-4882.

Wayne, L. G., Brenner, D. J., Colwell, R. R., Grimont, P. A. D., Kandler, O., Krichevsky, M. I., Moore, L. H., Moore, W. E. C., Murray, R. G. E. \& other authors (1987). International Committee on Systematic Bacteriology. Report of the ad hoc committee on reconciliation of approaches to bacterial systematics. Int J Syst Bacteriol 37, 463-464.

Weisburg, W. G., Barns, S. M., Pelletier, D. A. \& Lane, D. J. (1991). $16 \mathrm{~S}$ ribosomal DNA amplification for phylogenetic study. J Bacteriol 173, 697-703.

Wu, C., Lu, X., Qin, M., Wang, Y. \& Ruan, J. (1989). Analysis of menaquinone compound in microbial cells by HPLC. Microbiology [English translation of Microbiology (Beijing)] 16, 176-178.

Yumoto, I., Kawasaki, K., Iwata, H., Matsuyama, H. \& Okuyama, H. (1998). Assignment of Vibrio sp. strain ABE-1 to Colwellia maris sp. nov., a new psychrophilic bacterium. Int J Syst Bacteriol 48, 1357-1362.

Zhang, D.-C., Yu, Y., Xin, Y.-H., Liu, H.-C., Zhou, P.-J. \& Zhou, Y.-G. (2008). Colwellia polaris sp. nov., a psychrotolerant bacterium isolated from Arctic sea ice. Int J Syst Evol Microbiol 58, 1931-1934.

Zhang, L., Wang, Y., Dai, J., Tang, Y., Yang, Q., Luo, X. \& Fang, C. X. (2009). Bacillus korlensis sp. nov., a moderately halotolerant bacterium isolated from a sand soil sample in China. Int J Syst Evol Microbiol 59, 1787-1792. 